\title{
The incidence of cervical intraepithelial neoplasia in antenatal women by screening: a study in a semi urban area in Telangana, India
}

\author{
Beera Neelima $^{1 *}$, V. G. Vanamala ${ }^{2}$
}

\begin{abstract}
${ }^{1}$ Department of Obstetrics and Gynecology, Mallareddy Institute of Medical Sciences and Hospital, Suraram, Rangareddy, Hyderabad, India

${ }^{2}$ Department of Obstetrics and Gynecology, VRK Womens Medical College and Hospital and Research Center, Aziz Nagar, Rangareddy, Hyderabad, India
\end{abstract}

Received: 25 May 2017

Accepted: 29 May 2017

\section{*Correspondence:}

Dr. Beera Neelima,

E-mail: drneelimab@gmail.com

Copyright: ( ) the author(s), publisher and licensee Medip Academy. This is an open-access article distributed under the terms of the Creative Commons Attribution Non-Commercial License, which permits unrestricted non-commercial use, distribution, and reproduction in any medium, provided the original work is properly cited.

\begin{abstract}
Background: Cervical intraepithelial neoplasia is a premalignant cervical disease which may lead to cervical cancer. The screening of the cervical cancer includes the screening of cervical cytology as well as testing for oncogenic human papilloma viruses (HPV) since most of the precursor lesions appear in the women of child bearing age. The purpose of the present study was to evaluate the incidence of cervical intraepithelial neoplasia in antenatal women by screening with papanicolaou smear.

Methods: Macroscopic abnormalities such as cervicitis, polyps, erosions, nabothian cysts, hypertrophied cervix, growths and ulcers were noted. A cervical smear using Ayre's spatula was taken from the ecto cervix and spread on to a labeled slide and immediately fixed.

Results: Majority of the women were in the age group of 20-30 years in the study group. The overall mean age of the women in the study was around 25 years. The mean age at the time of menarche was around 14 years and at the time of marriage was approximately 22 years. On Pap smear, 55.2\% of the 1000 cases were normal, with inflammation seen in $408(40.8 \%)$ of the cases. $20(2 \%)$ of the patients in our study had low grade squamous intra epithelial lesion, while 7 patients $(0.2 \%)$ had high grade squamous intra epithelial lesion with two cases showing CIN II grading and 5 with CIN I.
\end{abstract}

Conclusions: An early detection of the same can lead to a proper and efficient treatment.

Keywords: Antenatal women, Cervical intraepithelial neoplasia, Cervical cancer, Pregnant women

\section{INTRODUCTION}

Cervical intraepithelial neoplasia (CIN), also called dysplasia or cervical squamous epithelial lesions is a premalignant cervical disease which may lead to cervical cancer. ${ }^{1,2}$ Cervical cancer is said to be the second most common cancer among the women with an estimated death rate of 231000 to 500000 new cases every year. ${ }^{2}$ The rate of incidence varies from country to country with almost $80 \%$ seen in the developing countries. The cause for this is said to be the low socio-economic conditions present in these countries where facilities for family planning, obstetric health and gynecological health conditions are poor with almost no cervical screening programmes. ${ }^{3}$ In India, the cervical cancer is the most common of all cancers in women and has known to account for $16 \%$ of them. Some of the risk factors stated are multiple sexual partners, early age at the first coitus, or partner with multiple sexual partners. ${ }^{4}$

The screening of the cervical cancer includes the screening of cervical cytology as well as testing for 
oncogenic human papilloma viruses (HPV) since most of the precursor lesions appear in the women of child bearing age..$^{5-9}$ Colposcopy and cervical biopsy with papanicolaou smear is usually included in the diagnosis. ${ }^{10}$ Pap smear is one of the most common and easy method of screening especially in the non-symptomatic case of early cervical neoplasia.

The purpose of the present study was to evaluate the incidence of cervical intraepithelial neoplasia in antenatal women by screening with papanicolaou smear

\section{METHODS}

This study was conducted by the department of Gynaecology at Mallareddy Institute of Medical sciences from February 2014 to April 2017. 1000 antenatal patients attending the Gynecology outpatient ward were randomly selected for the study. Patients with excessive and active vaginal bleeding, draining of liquor, excessive vaginal discharge, women with frank lesions on the cervix were excluded from the study.

The study protocol was explained to all the patients in detail and informed consent was taken from all of them. Detailed information regarding their obstetric and gynaecological was recorded and the marital status, age at first coitus, methods of contraceptives used (if any), history of multiple sexual partners of the women or spouse, and prior cytological examination if any were also noted. After a thorough general, physical examination the subject was put on the examination table in dorsal position and specutum was introduced into the vagina, exposing the cervix. Macroscopic abnormalities such as cervicitis, polyps, erosions, nabothian cysts, hypertrophied cervix, growths and ulcers were noted. A cervical smear using Ayre's spatula was taken from the ecto cervix and spread on to a labeled slide and immediately fixed.

After fixing, the slides were sent to the pathology department, where they were stained with pap stain. A single cyto pathologist read all the slides. Then the incidence of preinvasive or occutt lesions through smear reports, noted. If found necessary diagnostic quality test were performed namely a. colposcopy b. colposcopic directed biopsy and c. conisation. All patients who had abnormal smears were questioned about their knowledge on cervical cancer and CIN.

\section{RESULTS}

Majority of the women were in the age group of 20-30 years in the study group. These are the years when a women is at the peak of her sexual activity, which starts to decline as the years advance. lt is during this period that a woman should be alert regarding her sexual health. Very few of them were in the adolescent age group that is $20 \%$ (Table 1).
Table 1: Age wise distribution of the patients.

\begin{tabular}{|c|c|c|}
\hline Age & Number & Percentage \\
\hline $15-20$ years & 200 & 20 \\
\hline $21-25$ years & 600 & 60 \\
\hline $26-30$ years & 175 & 17.5 \\
\hline $30-35$ years & 25 & 2.5 \\
\hline
\end{tabular}

The overall mean age of the women in the study was around 25 years. The mean age at the time of menarche was around 14 years and at the time of marriage was approximately 22 years.

\section{Table 2: Bench marks ages of the patients.}

\begin{tabular}{|ll|}
\hline Benchmark & Age \\
\hline Mean age at menarche & $14 \pm 2.7$ \\
\hline Mean Age & $23.6 \pm 4.3$ \\
\hline Mean age at marriage & $22 \pm 4.9$ \\
\hline
\end{tabular}

Most of the women in the study were in their first pregnancy $(65.8 \%)$ while multi gravida was seen in 302 patients (Figure 1).

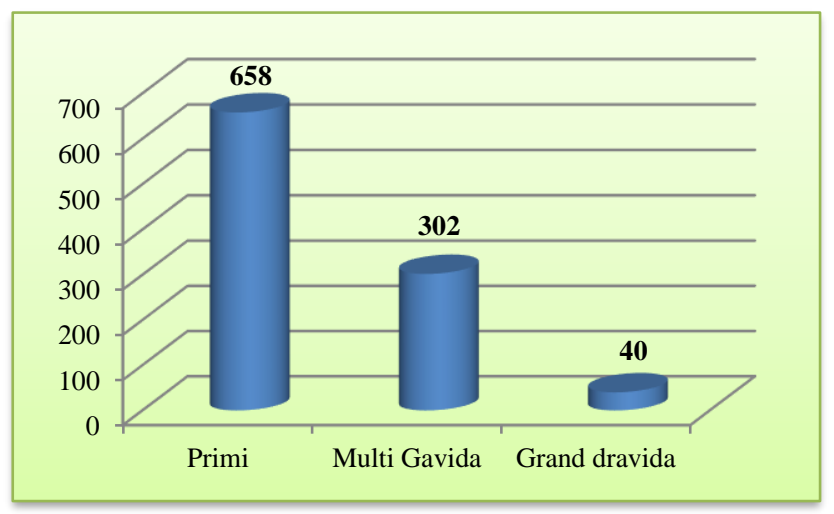

Figure 1: Status of gravida of patients.

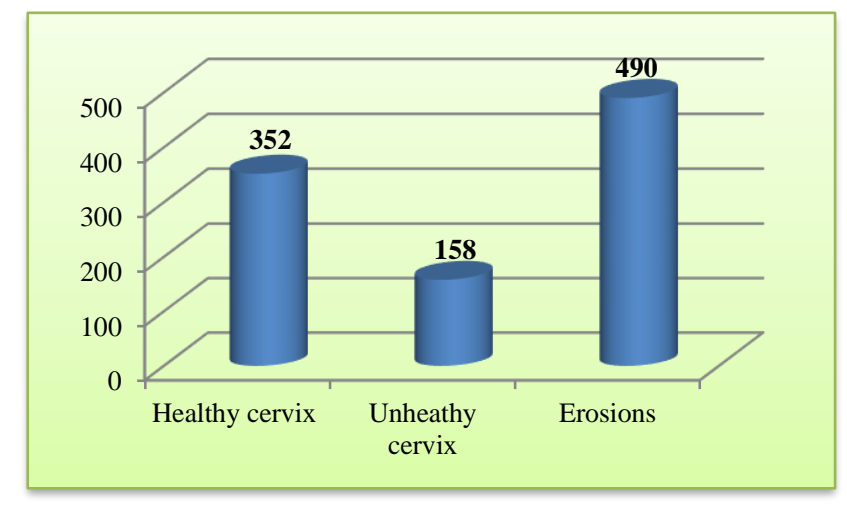

Figure 2: Clinical diagnosis.

$49 \%$ of the women had cervices with erosions and $15.8 \%$ of them had unhealthy cervix, with 352 (35.2\%) women having healthy cervix (Figure 2). 
On Pap smear, $55.2 \%$ of the 1000 cases were normal, with inflammation seen in $408(40.8 \%)$ of the cases. 38 patients $(3.8 \%)$ had squamous metaplasia and dysplasia was seen in 2 patients $(0.2 \%) .20(2 \%)$ of the patients in our study had low grade squamous intra epithelial lesion, while 7 patients $(0.2 \%)$ had high grade squamous intra epithelial lesion with one case each showing CIN II and CIN II grading and 5 with CIN I.

Table 3: Pap smear results.

\begin{tabular}{|lll|}
\hline Features & Number & Percentage \\
\hline Normal & 552 & 55.2 \\
\hline Inflammation & 408 & 40.8 \\
\hline Squamous metaplasia & 38 & 3.80 \\
\hline Dysplasia & 2 & 0.2 \\
\hline Chronic cevicitis & 10 & 1 \\
\hline LSIL & 20 & 2 \\
\hline HSIL & 7 & \\
\hline CIN I & 4 & 0.7 \\
\hline CIN II & 2 & \\
\hline CIN III & 1 & \\
\hline
\end{tabular}

LSIL $=$ Low grade squamous intra epithelial lesion, HSIL $=$ High grade squamous intra epithelial lesion, $\mathrm{CIN}=$ Cervical intraepithelial neoplasia

Table 4: Knowledge of CIN among the patients.

\begin{tabular}{|lll|}
\hline Cause & Knowledgeable & Non-knowledgeable \\
\hline Symptoms & $132(32.4 \%)$ & $276(67.6 \%)$ \\
\hline Treatment & $283(69.7 \%)$ & $242(59.3 \%)$ \\
\hline
\end{tabular}

\section{DISCUSSION}

It has been observed that the case of cervical cancer has increased in young women between 20- 30 years of age in the past few years. ${ }^{11}$ This has been attributed to the increase in the increased rate of human papilloma virus infection and the increased age of the first child birth. Cervical pap smear is recommended as a part of routine examination for pregnant women for screening for abnormal cervix.

Predisposition towards cervical cancer may be the small age of the patient at her first sexual encounter and multiple sexual partners. Polygamy is reported to increase the risk of cervical cancer by twofolds. ${ }^{12}$ A spouse with multiple partners is also known to be a risk factor for the development of human papilloma virus, which is one of the main causes of cervical cancer. ${ }^{13}$

The mean age in our study was $23.6 \pm 4.3$ years, with the most predominant age group being 21.25 years. The mean age at menarche was $14 \pm 2.7$ and at the time of marriage was $22 \pm 4.9$. in a study by Schiff et al, the mean age was 27.6 year with women having less than high school of education. The mean age of the first intercourse for these women was 16.9 years. ${ }^{14}$
In the present study, the incidence of CIN was $2.7 \%$. In a study by Al-Halal in 2012, the incidence of CIN was observed to be $1.3-2.7 \%$, HGSIL type changes undergo spontaneous regression during confinement from 48$70 \% .^{15,16}$ In another study the prevalence if CIN was around $12 \%$ out of which HSIL was seen in $2 \%$ of the cases. ${ }^{12}$ In a retrospective study on Post coital bleeding by Rosenthal et al, 12 out of 314 cases showed invasive cancer out of which 10 were cervical. ${ }^{17}$ d'OttavianoMorelli reported an HSiL (both CIN II and CIN III ) positivity on 396 patietns out of $100000 .^{18}$

A retrospective study by Rosenthal et al of 314 women with PCB showed 12 cases of invasive cancer (3.8\%): ten were cervical or vaginal cancers and two endometrial cancers. Eight out of the ten cervical /vaginal cancers were clinically apparent. Four of these ten had normal smears before being referred for further investigation of PCB. ${ }^{19}$

Low rates of progression have been observed in various studies during pregnancy, while other studies have observed a higher postpartum regression rates of $37-$ $74 \%$ of CIN. ${ }^{20-24}$ The limitation of our study are the low number of CIN patients to give a proper evaluation of the progression of the disease.

The level of knowledge among the abnormal smear patients was $32 \%$ and $40 \%$ regarding the cause and symptoms of neoplasia or cervical cancer while the treatment was known to majority of them. In a similar study in Nigeria, the symptoms and cause was known to $25 \%$ of the patients, while in a study in Lagos, less than $20 \%$ of the patients knew about this disease. ${ }^{12,25}$

\section{CONCLUSION}

There is a low incidence of cervical intraepithelial neoplasia in our geographical area. However, an early detection of the same can lead to a proper and efficient treatment with conservative management so as to not affect the growing fetus as well as the mother. The general knowledge among the women regarding the disease was low, so it is also imperative to educate the women the symptoms of the disease as well as the practices that can lead to it along with the prevention.

\section{Funding: No funding sources}

Conflict of interest: None declared

Ethical approval: The study was approved by the Institutional Ethics Committee

\section{REFERENCES}

1. Montz FJ. Management of high-grade cervical intraepithelial neoplasia and low-grade squamous intraepithelial lesion and potential complications. Clin Obstet Gynecol. 2000;43:394. 
2. World Health Organization. Available at http://www.who.int/en/. [Last Accessed on 2003 Aug 7].

3. IARC (International Agency for Research on Cancer) An Introduction to Cervical Intraepithelial Neoplasia (CIN). chapter 2. 2001.

4. Jemal A, Tiwari RC, Murray T. Cervical and vaginal cancer. Berek and Novac's gynecology. 14. Philadelphia: Wolters Kluwer Publishers; 2009.

5. Frega A, Scirpa P, Corosu R, Verrico M, Scarciglia ML, Primieri MR et al. Clinical management and follow-up of squamous intraepithelial cervical lesions during pregnancy and postpartum. Anticancer Res. 2007;27:2743-6.

6. Bano F, Kolhe S, Zamblera D, Jolaoso A, Folayan O, Page L et al. Cervical screening in under 25s: a highrisk young population. Eur J Obstet Gynecol Reprod Biol. 2008;139:86-9.

7. Bosch FX, de Sanjosé S. The epidemiology of human papillomavirusinfection and cervical cancer. Dis Markers. 2007;23:213-27.

8. Lowy DR, Schiller JT. Prophylactic human papillomavirus vaccines. J Clin Invest. 2006;116:1167-73.

9. Snijders PJ, Steenbergen RD, Heideman DA, Meijer CJ. HPV-mediated cervical carcinogenesis: concepts and clinical implications. J Pathol. 2006;208:152-64.

10. Massad LS, Einstein MH, Huh WK, Katki HA, Kinney WK, Schiffman M et al. 2012 updated consensus guidelines for the management of abnormal cervical cancer screening tests and cancer precursors. J Low Genit Tract Dis. 2013;17:S1.

11. Ushijima KJ. Current status of gynecologic cancer in Japan. J Gynecologic Oncol. 2009;20:67-71.

12. Adisa JO, Sa'adatu BT, Bukar M, Egbujo EC. Prevalence of cervical intraepithelial neoplasia in relation to knowledge, attitudes/beliefs, and practices among university students in North-Eastern Nigeria. Annals Trop Med Public Health. 2013;6(4):418-21.

13. Bayo S, Bosch FX, de Sanjose S, Muñoz N, Combita $\mathrm{AL}$, Coursaget $\mathrm{P}$ et al. Risk factors of invasive cervical cancer in Mali. Int $\mathbf{J}$ Epidemiol. 2000;31:202-9.

14. Schiff M, Becker TM, Masuk M, Asselt-King LV, Wheeler CM, Altobelli KK et al. Altobelli, Charles Q. North, and Andre J. Nahmias. Risk factors for cervical intraepithelial neoplasia in Southwestern American Indian women. Am $\mathrm{J}$ Epidemiol. 2000;152(8):716-26.

15. Al-Halal H, Kezouh A, Abenhaim H. Incidence and obstetrical outcomes of cervical intraepithelial neoplasia and cervical cancer in pregnancy. Archives Gynecol Obstet. 2012;287(2):245-50.
16. Ahdoot D, Van Nostrand KM, Nguyen NJ, Tewari DS, Kurasaki T, DiSaia PJ et al. The effect of route of delivery on regression of abnormal cervical cytologic findings in the postpartum period. Am J Obstet Gynecol. 1998;178(6):1116-20.

17. Obeidat RA, Saidi SA. Prevalence of high-grade cervical intraepithelial neoplasia (CIN) and cervical cancer in women with post-coital bleeding (PCB) and negative smear: a retrospective study. Gynecol Obstet. 2012;2:127.

18. d'Ottaviano-Morelli MG, Zeferino L, Cecatti JG, Terrabuio DR, Martinez EZ. Prevalence of cervical intraepithelial neoplasia and invasive carcinoma based on cytological screening in the region of Campinas, São Paulo, Brazil. Cadernos de Saúde Pública. 2012;20(1):153-9.

19. Rosenthal AN, Panoskaltsis T, Smith T, Soutter WP. The frequency of significant pathology in women attending a general gynaecological service for postcoital bleeding. BJOG. 2001;108(1):103-6.

20. Jain AG, Higgins RV, Boyle MJ. Management of low-grade squamous intraepithelial lesions during pregnancy. Am J Obstet Gynecol. 1997;177:298302.

21. Holowaty P, Miller AB, Rohan T, To T. Natural history of dysplasia of the uterine cervix. J Natl Cancer Inst. 1999;91:252-8.

22. Paraskevaidis E, Koliopoulos G, Kalantaridou S, Pappa L, Navrozoglou I, Zikopoulos K et al. Management and evolution of cervical intraepithelial neoplasia during pregnancy and postpartum. Eur J Obstet Gynecol and Reprod Biol. 2002;104:67-9.

23. Fader AN, Alward EK, Niederhauser A, Chirico C, Lesnock JL, Zwiesler DJ et al. Cervical 7dysplasia in pregnancy: a multi-institutional evaluation. Am J Obstet Gynecol. 2010;203(2):113.e1-6.

24. Lurain JR, Gallup DG. Management of abnormal PAP smears in pregnancy. Obstet Gynecol. 1979;53:484-8.

25. Anorlu RI, Banjo AA, Odoemhum C. Cervical cancer screening: Level of awareness in women attending a primary health care facility in Lagos. Niger Postgrad Med J. 2000;70:25-8.

Cite this article as: Neelima B, Vanamala VG. The incidence of cervical intraepithelial neoplasia in antenatal women by screening: a study in a semi urban area in Telangana, India. Int J Reprod Contracept Obstet Gynecol 2017;6:2887-90. 